\title{
KERAGAAN ZOOTEKNIS DAN BIOMETRIK-MORFOLOGIS IKAN LELE MUTIARA, Clarias gariepinus ALBINO
}

\section{Bambang Iswanto\#, Rommy Suprapto, Imron, Joni Haryadi, Pudji Suwargono, Maya Febriana Pangestika, dan IImalizanri}

\author{
Balai Riset Pemuliaan Ikan \\ Jl. Raya 2 Pantura Sukamandi, Patokbeusi, Subang, Jawa Barat
}

(Naskah diterima: 7 September 2021; Revisi final: 9 Oktober 2021; Disetujui publikasi: 10 Oktober 2021)

\begin{abstract}
ABSTRAK
Pemuliaan ikan lele Afrika, Clarias gariepinus melalui seleksi individu selama tiga generasi telah menghasilkan strain baru ikan lele tumbuh cepat yang diberi nama Mutiara. Pemijahan induk ikan lele Mutiara dapat menghasilkan benih albino. Keragaan zooteknis dan karakteristik fenotipe-morfologis ikan lele Mutiara albino perlu dieksplorasi untuk mengevaluasi potensi pengembangannya. Penelitian ini bertujuan mendapatkan informasi keragaan pertumbuhan, sintasan, hubungan panjang-bobot, faktor kondisi, dan karakteristik biometrik ikan lele Mutiara albino dibandingkan yang berwarna normal. Pengamatan keragaan pertumbuhan dilakukan selama 20 hari tahap pemeliharaan larva, 30 hari tahap pendederan dan 45 hari tahap pembesaran. Analisis hubungan panjang-bobot dan faktor kondisi, serta karakterisasi biometrik dilakukan pada akhir tahap pembesaran. Hasil penelitian ini menunjukkan bahwa keragaan pertumbuhan ikan lele Mutiara albino berdasarkan parameter bobot selama tahap pemeliharaan larva, pendederan, dan pembesaran tidak berbeda dari yang berwarna normal $(P>0,05)$; sedangkan keragaan pertumbuhan berdasarkan parameter panjang totalnya lebih rendah $(P<0,05)$. Sintasan ikan lele Mutiara albino selama tahap pemeliharaan larva, pendederan, dan pembesaran tidak berbeda $(P>0,05)$ dari yang berwarna normal. Hubungan panjang-bobot ikan lele Mutiara albino bersifat alometrik positif $\left(W=0,0021 L^{3,45}\right)$, sama dengan yang berwarna normal $\left(\mathrm{W}=0,0044 \mathrm{~L}^{3,16}\right)$. Ikan lele Mutiara albino memiliki tubuh yang lebih gemuk (faktor kondisi sebesar 0,88 $\pm 0,08$ ) dibandingkan yang berwarna normal (faktor kondisi sebesar $0,73 \pm 0,05$ ). Secara biometrik, ikan lele Mutiara albino memiliki proporsi kepala yang lebih besar dan jumlah jari-jari sirip punggung dan sirip dubur yang lebih sedikit dibandingkan yang berwarna normal. Secara umum, keragaan aspek zooteknis ikan lele Mutiara albino relatif sama dengan yang berwarna normal, sehingga potensial sebagai komoditas budidaya.
\end{abstract}

\section{KATA KUNCl: biometrik; faktor kondisi; hubungan panjang-bobot; ikan lele Mutiara, Clarias gariepinus albino; pertumbuhan.}

\section{ABSTRACT: Zootechnical performance and biometric characteristics of the albino Mutira African catfish, Clarias gariepinus. By: Bambang Iswanto, Rommy Suprapto, Imron, Joni Haryadi, Pudji Suwargono, Maya Febriana Pangestika, and IImalizanri}

\begin{abstract}
A breeding program of the African catfish, Clarias gariepinus via three generations of individual selection resulted in a new fast-growing strain, namely M utiara. Breeding of theM utiara African catfish might result in albino individuals. Zootechnical and morphological-phenotypic performances of the albino should be evaluated to determine its potential as an aquaculture strain. The present study aimed to obtain information on the growth performance, survival, lengthweight relationship, condition factors, and biometric characteristics of the albino compared to those of the normal ones. The growth performance was observed during 20 days of larval rearing, 30 days of nursery, and 45 days of growout phases. While, length-weight relationship, condition factors, and biometric characteristics were measured at the end of the grow-out phase. The present study revealed that the growth performance of the albino based on body weight during larval rearing, nursery, and grow-out phases was not different $(P>0.05)$, whereas its growth performance based on total length was inferior $(P<0.05)$ to that of the normal ones. The survival rate of the albino during larval rearing,
\end{abstract}

\footnotetext{
\# Korespondensi: Balai Riset Pemuliaan Ikan

Jl. Raya 2 Pantura Sukamandi, Patokbeusi, Subang, Jawa Barat, Indonesia

E-mail: bambang.is031@gmail.com
} 
nursery, and grow-out phases was not different $(P>0.05)$ to that of thenormal ones. Length-weight relationship of the albino was positive allometric $\left(\mathrm{W}=0.0021 \mathrm{~L}^{3.45}\right)$, similar to that of the normal ones $\left(\mathrm{W}=0.0044 \mathrm{~L}^{3.16}\right)$. The albino was more rotund (condition factor of $0.88 \pm 0.08$ ) compared to the normal ones (condition factor of $0.73 \pm 0.05$ ). Biometrically, the albino has a bigger head portion and fewer dorsal and anal fin rays than the normal ones. In general, the zootechnical aspect of albino M utiara African catfish is relatively similar to that of the normal ones meaning that it has the potential to be considered as an aquaculture strain candidate.

\section{KEYWORDS: albino Mutiara African catfish, Clarias gariepinus; biometric; condition factor; growth; length- weight relationship}

\section{PENDAHULUAN}

Ikan lele Afrika, Clarias gariepinus telah lama dibudidayakan di Indonesia, sejak diintroduksinya ikan lele dumbo pada tahun 1985. Selanjutnya, introduksi ikan lele Afrika untuk keperluan budidaya di Indonesia kembali dilakukan beberapa kali, baik dari Afrika maupun melalui negara lain. Budidaya ikan lele dumbo dan strain-strain introduksi lainnya tersebut berkembang pesat pada masa-masa awal introduksinya, tetapi kemudian mengalami penurunan karena penerapan manajemen genetik induk yang tidak tepat, sehingga diperlukan upaya pemuliaan.

Pemuliaan ikan lele Afrika di Indonesia telah dilakukan oleh Balai Penelitian Pemuliaan Ikan (BPPI) Sukamandi melalui seleksi individu menghasilkan varietas unggul ikan lele Mutiara yang dirilis berdasarkan Keputusan Menteri Kelautan dan Perikanan Nomor: 77/KEPMEN-KP/2015. Selain menghasilkan benih yang berwarna normal, beberapa pemijahan pasangan induk ikan lele Mutiara yang berwarna normal dapat menghasilkan benih albino, dengan persentase jumlah benih albino mendekati $25 \%$ (Iswanto et al., 2020a).

Strain-strain ikan lele Afrika lain yang digunakan dalam kegiatan budidaya juga dapat menghasilkan keturunan albino dan beberapa karakteristiknya telah dilaporkan, antara lain karakteristik biometrik, perkembangan embrio dan larva, pertumbuhan, sintasan, fekunditas, keberhasilan pemijahan, hubungan panjang-bobot, faktor kondisi, kemudahan penangkapan, kanibalisme, komposisi proksimat, mineral, asam amino, serta asam lemak (Prinsloo \& Schoonbee, 1989; Prinsloo et al., 1989a; 1989b; 1990; Hoffman et al., 1995a; 1995b; Iswanto et al., 2013a; 2013b; 2015; 2016; 2020b; Onyia et al. 2016; 2018; Umanah \& Harry, 2017). Namun demikian, informasi keragaan zooteknis dan karakteristik fenotipemorfologis ikan lele albino pada strain ikan lele Mutiara hasil pemuliaan BPPI Sukamandi belum diketahui, sehingga perlu dieksplorasi untuk mengevaluasi potensi pengembangannya. Penelitian ini bertujuan untuk mendapatkan informasi keragaan zooteknis dan karakteristik fenotipe-morfologis ikan lele Mutiara albino, meliputi keragaan pertumbuhan, sintasan, hubungan panjang-bobot, faktor kondisi, dan karakteristik biometrik.

\section{BAHAN DAN METODE}

Karakterisasi keragaan zooteknis dan fenotipemorfologis ikan lele Mutiara albino dibandingkan dengan yang berwarna normal pada penelitian ini dilakukan di Balai Riset Pemuliaan Ikan (BRPI) Sukamandi pada bulan Januari-M ei 2021. Populasi ikan lele Mutiara albino dan warna normal yang digunakan dalam penelitian ini masing-masing dihasilkan dari pemijahan lima pasang ikan lele Mutiara albino dan warna normal hasil peremajaan stok tahun 2020. Pemijahan tersebut dilakukan pada tanggal 7 Januari 2021.

Sebanyak 1.000 ekor larva hasil penetasan dari setiap pasangan induk dipelihara selama 20 hari dalam akuarium-akuarium berukuran $60 \mathrm{~cm}$ x $40 \mathrm{~cm} \times 30 \mathrm{~cm}$ di dalam ruangan panti pembenihan. Selanjutnya, sebanyak 200 ekor benih hasil pemeliharaan larva dari masing-masing pasangan induk dipelihara di luar ruangan selama 30 hari dalam hapa-hapa berukuran 1 $\mathrm{m} \times 1 \mathrm{~m} \times 0,5 \mathrm{~m}$ yang ditempatkan dalam kolam beto $\mathrm{n}$ berukuran $5 \mathrm{~m} \times 3 \mathrm{~m}$ x 0,7 $\mathrm{m}$. Pada tahap pembesaran, sebanyak 50 ekor benih dari masing-masing pasangan induk dipelihara secara bersama (komunal) selama 45 hari dalam sebuah kolam beton berukuran $5 \mathrm{~m} \times 3 \mathrm{~m}$ $x$ 0,7 $\mathrm{m}$. Teknik pemeliharaan (manajemen pemberian pakan dan manajemen kualitas air) selama tahap pemeliharaan larva, pendederan, dan pembesaran tersebut serupa dengan teknik pemeliharaan yang digunakan dalam penelitian karakterisasi ikan lele Afrika albino asal Thailand di BRPI Sukamandi sebelumnya (Iswanto et al., 2020b).

Selama tahap pemeliharaan larva, pendederan, dan pembesaran tersebut parameter-parameter kualitas air yang meliputi suhu, pH, kadar amonia, dan kadar nitrit diukur pada awal setiap tahap pemeliharaan, kemudian dilanjutkan dua kali dalam seminggu. Pengukuran suhu dan $\mathrm{pH}$ dilakukan dengan menggunakan alat $\mathrm{pH}$ meter digital, sedangkan kadar amonia dan kadar nitrit diukur secara spektrofotometri. Pengukuran kualitas air tersebut dilakukan pada pagi hari (pukul 07:00) dan sore hari (pukul 15:00). 


\section{Evaluasi Keragaan Pertumbuhan dan Sintasan}

Pada akhir tahap pemeliharaan larva (20 hari), tahap pendederan (30 hari), dan tahap pembesaran (45 hari) dilakukan penghitungan jumlah benih yang masih hidup (sintasan), serta pengukuran panjang total (menggunakan mistar ukur dengan ketelitian 0,05 cm) dan penimbangan bobot (menggunakan neraca digital dengan ketelitian $0,01 \mathrm{~g}$ ) terhadap masing-masing sebanyak 60 ekor sampel ikan lele Mutiara albino dan warna normal. Data ukuran panjang total dan bobot ikan lele Mutiara albino pada akhir tahap pemeliharaan larva, pendederan, dan pembesaran dibandingkan dengan yang berwarna normal. Perbandingan keragaan pertumbuhan dan sintasan tersebut dilakukan dengan menggunakan uji t pada tingkat kepercayaan 95\% dengan bantuan program komputer Microsoft Office Excel (Microsoft Corp.).

\section{Analisis Hubungan Panjang-Bobot dan Faktor Kondisi}

Data ukuran panjang total dan bobot ikan lele Mutiara albino dan warna normal pada akhir tahap pembesaran digunakan untuk menganal isis hubungan antara panjang (L) dengan bobot (W) menggunakan analisis regresi mengikuti persamaan $\mathrm{W}=\mathrm{aL}^{\mathrm{b}}$, dengan (a) merupakan konstanta dan (b) merupakan eksponen (Froese, 2006). Selanjutnya, data ukuran panjang total dan bobot tersebut digunakan untuk menganalisis faktor kondisi ikan lele Mutiara albino dan warna normal. Faktor kondisi (K) dihitung dengan menggunakan rumus Faktor kondisi Fulton $\mathrm{K}=100 \times\left(\mathrm{W} / \mathrm{L}^{3}\right)$ (Froese, 2006). Analisis data tersebut dilakukan dengan bantuan program komputer Microsoft Office Excel (Microsoft Corp.).

\section{Karakterisasi Biometrik-Morfologis}

Karakterisasi biometrik-morfologis ikan lele Mutiara al bino dilakukan pada akhir tahap pembesaran dibandingkan dengan yang berwarna normal. Karakterisasi biometrik-morfologis tersebut dilakukan pada karakter morfometrik dan meristik berdasarkan metode standar karakterisasi biometrik spesies ikan lele Afrika (Teugels, 1986). Karakter-karakter morfometrik ikan lele Mutiara warna normal dan albino pada akhir tahap pembesaran tersebut diukur menggunakan jangka so rong digital (dengan ketelitian $0,01 \mathrm{~mm}$ ). Data karakter morfometrik yang diperoleh kemudian dianalisis dengan analisis komponen utama ( $P C A=$ principal component analysis) berdasarkan matriks kovarian, sesuai metode analisis data karakteristik morfometrik ikan lele Afrika (Agnese et al., 1997; Iswanto et al., 2020b). Selanjutnya, skor masing-masing sampel ikan lele Mutiara albino dan warna normal yang diperoleh dari hasil analisis komponen utama diplot dalam diagram pencar (scat- ter plot) di antara dua sumbu komponen utama untuk mengetahui bentuk sebarannya. Proses analisis data tersebut dilakukan dengan menggunakan program komputer SYSTAT 11 (Systat Software Inc.).

\section{HASIL DAN BAHASAN}

\section{Keragaan Pertumbuhan dan Sintasan}

Hasil pengukuran panjang total, bobot, sintasan, dan laju pertumbuhan spesifik ikan lele Mutiara albino dan warna no rmal pada akhir tahap pemeliharaan larva, pendederan, dan pembesaran ditunjukkan pada Tabel 1. Selama tahap pemeliharaan larva, pendederan, dan pembesaran tersebut ikan lele Mutiara albino dan warna normal memiliki sintasan yang sama $(P>0,05)$. Pada saat menetas larva ikan lele Mutiara albino memiliki panjang total yang lebih kecil $(P<0,05)$ dibandingkan dengan ikan lele Mutiara warna normal. Pada akhir tahap pemeliharaan larva, benih ikan lele Mutiara albino dan warna normal memiliki panjang total dan bobot yang sama $(P>0,05)$. Selanjutnya, panjang total akhir tahap pendederan benih ikan lele Mutiara albino lebih kecil $(P<0,05)$ dibandingkan yang berwarna normal, tetapi bobot dan laju pertumbuhan spesifiknya adalah sama $(P>0,05)$. Demikian pula pada akhir tahap pembesaran, ikan lele Mutiara albino memiliki panjang total yang lebih kecil $(P<0,05)$ dibandingkan yang berwarna normal, dengan bobot dan laju pertumbuhan spesifik yang sama $(P>0,05)$. Hasil pengukuran panjang total dan bobot selama tahap pemeliharaan larva, pendederan, dan pembesaran tersebut menunjukkan bahwa keragaan pertumbuhan ikan lele Mutiara albino berdasarkan parameter bobot relatif sama dengan ikan lele Mutiara warna normal, sedangkan keragaan pertumbuhan berdasarkan parameter panjang total lebih rendah dibandingkan yang berwarna normal.

Keragaan pertumbuhan ikan lele Mutiara albino berdasarkan parameter bobot yang relatif sama dengan ikan lele Mutiara warna normal pada penelitian ini berbeda dari keragaan pertumbuhan ikan-ikan lele Afrika albino yang lain. Ikan lele Afrika albino di Afrika Selatan, Nigeria maupun ikan lele Afrika albino di Indonesia yang berasal dari M esir dan Thailand memiliki keragaan pertumbuhan (berdasarkan bobot maupun panjang total) yang lebih rendah dibandingkan yang berwarna normal (Prinsloo \& Schoonbee, 1989; Umanah \& Harry, 2017; Onyia et al., 2016; Iswanto et al., 2013a; 2020b). Lebih rendahnya keragaan pertumbuhan ikan-ikan lele Afrika albino tersebut terutama dikarenakan lebih rendahnya tingkat respons terhadap pakan yang diberikan (Iswanto et al., 2020b). Namun demikian, hal tersebut tidak terjadi pada ikan lele Mutiara albino. Respons ikan lele Mutiara albino dalam memakan pakan yang diberikan tidak berbeda 
Tabel 1. Panjang total, bo bot, sintasan, dan laju pertumbuhan spesifik ikan lele Mutiara (Clarias gariepinus) albino selama tahap pemeliharaan larva, pendederan, dan pembesaran dibandingkan dengan yangberwarna normal

Table 1. Total length, body weight, survival, and specific growth rate of albino Mutiara African catfish (Clarias gariepinus) during larval rearing, nursery, and grow-out phases compared to those of the normal ones

\begin{tabular}{|c|c|c|}
\hline \multirow{2}{*}{$\begin{array}{l}\text { Parameter } \\
\text { Parameters }\end{array}$} & \multicolumn{2}{|c|}{$\begin{array}{l}\text { Ikan lele Mutiara } \\
\text { Mutiara African catfish }\end{array}$} \\
\hline & Albino (Albino) & Normal (Normal) \\
\hline $\begin{array}{l}\text { Panjang total larva yang baru menetas } \\
\text { Total length of newly hatched larvae }(\mathrm{mm})\end{array}$ & $5.21 \pm 0.42^{\mathrm{a}}$ & $6.27 \pm 0.29^{b}$ \\
\hline $\begin{array}{l}\text { Panjang total akhir tahap pemeliharaan larva } \\
\text { Total length at the end of larval rearing phase }(\mathrm{cm})\end{array}$ & $2.04 \pm 0.11^{\mathrm{a}}$ & $2.13 \pm 0.11^{\mathrm{a}}$ \\
\hline $\begin{array}{l}\text { Bobot akhir tahap pemeliharaan larva } \\
\text { Body weight at the end of larval rearing phase (g) }\end{array}$ & $0.09 \pm 0.01^{\mathrm{a}}$ & $0.09 \pm 0.02^{\mathrm{a}}$ \\
\hline $\begin{array}{l}\text { Sintasan tahap pemeliharaan larva } \\
\text { Survival rate during larval rearing phase }(\%)\end{array}$ & $73.70 \pm 3.28^{\mathrm{a}}$ & $75.18 \pm 2.91^{\mathrm{a}}$ \\
\hline $\begin{array}{l}\text { Panjang total akhir tahap pendederan } \\
\text { Total length at the end of nursery phase }(\mathrm{cm})\end{array}$ & $8.88 \pm 0.20^{\mathrm{a}}$ & $9.59 \pm 0.22^{b}$ \\
\hline $\begin{array}{l}\text { Bobot akhir tahap pendederan } \\
\text { Body weight at the end of nursery phase }(\mathrm{g})\end{array}$ & $6.45 \pm 0.54^{\mathrm{a}}$ & $6.51 \pm 0.30^{\mathrm{a}}$ \\
\hline $\begin{array}{l}\text { Laju pertumbuhan spesifik tahap pendederan (\%hari) } \\
\text { Specific growth rate during nursery phase (\%dday) }\end{array}$ & $14.11 \pm 0.36^{\mathrm{a}}$ & $14.14 \pm 0.45^{\mathrm{a}}$ \\
\hline $\begin{array}{l}\text { Sintasan tahap pendederan } \\
\text { Survival rate duringnursery phase }(\%)\end{array}$ & $80.33 \pm 1.61^{\mathrm{a}}$ & $83.30 \pm 6.86^{a}$ \\
\hline $\begin{array}{l}\text { Panjang total akhir tahap pembesaran } \\
\text { Total length at the end of grow-out phase }(\mathrm{cm})\end{array}$ & $24.9 \pm 2.4^{\mathrm{a}}$ & $27.2 \pm 2.6^{b}$ \\
\hline $\begin{array}{l}\text { Bobot akhir tahap pembesaran } \\
\text { Body weight at the end of grow-out phase }(\mathrm{g})\end{array}$ & $140.0 \pm 44.7^{\mathrm{a}}$ & $152.2 \pm 44.0^{\mathrm{a}}$ \\
\hline $\begin{array}{l}\text { Laju pertumbuhan spesifik tahap pembesaran (\%hari) } \\
\text { Specific growth rate during grow-out phase (\%dday) }\end{array}$ & 7.00 & 6.84 \\
\hline $\begin{array}{l}\text { Sintasan tahap pembesaran } \\
\text { Survival rate during grow-out phase }(\%)\end{array}$ & 72.37 & 71.43 \\
\hline
\end{tabular}

Keterangan: Huruf superskrip yang berbeda pada baris yang sama menunjukkan berbeda nyata $(P<0,05)$

Note: $\quad$ Different superscript letters in the same row indicate significant difference $(P<0.05)$

dari ikan lele Mutiara warna normal, yakni sama-sama merespons dengan baik. Hal tersebut menunjukkan bahwa ikan lele Afrika albino yang dihasilkan dari pasangan induk hasil pemuliaan yang telah ditingkatkan keragaan pertumbuhannya melalui program seleksi dapat memiliki keragaan pertumbuhan yang relatif sama dengan yang berwarna normal.

Kondisi parameter-parameter kualitas air media pemeliharaan ikan lele Mutiara albino dan warna normal selama tahap pemeliharaan larva, pendederan, dan pembesaran pada penelitian ini ditunjukkan pada Tabel 2. Secara umum, nilai parameter-parameter kualitas air media pemeliharaan tersebut masih berada dalam kisaran nilai yang direkomendasikan untuk pemeliharaan ikan lele Afrika (Degani et al., 1988; Schram et al., 2010; Ajani \& Adeyemo, 2012; Ndubuisi et al., 2015).

\section{Hubungan Panjang-Bobot dan Faktor Kondisi}

Hasil analisis hubungan antara panjang total (L) dengan bobot (W) ikan lele Mutiara albino pada akhir tahap pembesaran dengan menggunakan persamaan $W=a L^{b}$ berbentuk $W=0,0021 L^{3,45}$; sedangkan pada ikan lele Mutiara yang berwarna normal berbentuk $W=0,0044 L^{3,16}$ (Gambar 1). Hasil analisis hubungan panjang-bobot tersebut menunjukkan bahwa nilai eksponen pertumbuhan panjang total (b) kedua jenis ikan lele Mutiara bernilai lebih dari 3. Hal tersebut mengindikasikan bahwa pola hubungan panjang-bobot pada ikan lele Mutiara albino dan warna normal bersifat alometrik positif, yakni ikan lele Mutiara albino dan warna normal yang berukuran besar memiliki pertambahan tinggi atau lebar yang lebih besar dibandingkan pertambahan panjangnya jika dibandingkan dengan ikan-ikan lele Mutiara yang 
Tabel 2. Kualitas air media pemeliharaan ikan lele Mutiara (Clarias gariepinus) albino dan warna normal selama tahap pemeliharaan larva, pendederan, dan pembesaran

Table 2. Water quality during larval rearing, nursery, and grow-out phases of albino and normal Mutiara African catfish (Clarias gariepinus)

\begin{tabular}{lcccc}
\hline \multirow{2}{*}{$\begin{array}{c}\text { Parameter } \\
\text { Parameters }\end{array}$} & $\begin{array}{c}\text { Ikan lele Mutiara } \\
\text { Mutiara African catfish }\end{array}$ & $\begin{array}{c}\text { Pem eliharaan larva } \\
\text { Larval rearing }\end{array}$ & $\begin{array}{c}\text { Pendederan } \\
\text { Nursery }\end{array}$ & $\begin{array}{c}\text { Pembesaran } \\
\text { Grow-out }\end{array}$ \\
\hline Suhu & Albino (Albino) & $26.3-28.8$ & $24.4-33.2$ & $26.2-32.8$ \\
Temperature ( ${ }^{\circ} \mathrm{C}$ ) & Normal (Normal) & $26.8-29.4$ & $24.5-33.9$ & $26.2-33.1$ \\
\cline { 3 - 5 } & Albino (Albino) & $7.30-7.83$ & $7.11-7.50$ & $7.38-7.48$ \\
$\mathrm{pH}$ & Normal (Normal) & $7.52-7.88$ & $7.07-7.44$ & $7.28-7.45$ \\
\cline { 3 - 5 } & Albino (Albino) & $<0.1440$ & $<0.4982$ & $<0.5631$ \\
Amonia & Normal (Normal) & $<0.0944$ & $<0.5174$ & $<0.5862$ \\
Ammonia (mg/L) & Albino (Albino) & $<0.0077$ & $0.0049-1.1157$ & $0.0039-1.6827$ \\
Nitrit & Normal (Normal) & $<0.0064$ & $0.0049-1.1345$ & $0.0039-1.8268$ \\
Nitrite (mg/L) & & & &
\end{tabular}

berukuran kecil. Dengan kata lain, ikan lele Mutiara albino dan warna normal yang berukuran besar memiliki proporsi badan yang lebih gemuk dibandingkan ikanikan lele Mutiara yang berkuran kecil. Hal tersebut dikarenakan ikan-ikan lele Mutiara yang berukuran besar bersifat lebih banyak (lebih rakus) mengonsumsi pakan yang diberikan dan memiliki efisiensi pemanfaatan pakan yang lebih tinggi dibandingkan dengan ikan-ikan lele Mutiara yang berukuran kecil.
Ikan-ikan lele Afrika albino yang lain memiliki pola hubungan panjang-bobot yang berbeda-beda. Pola hubungan panjang-bobot ikan lele Afrika albino koleksi BRPI Sukamandi yang berasal dari Thailand juga bersifat alometrik positif (Iswanto et al., 2020b), sedangkan pada ikan lele Afrika albino yang berasal dari Mesir bersifat alometrik negatif (Iswanto et al., 2013b). Ikan Iele Afrika di Nigeria yang dipelihara dalam kolam sistem air mengalir memiliki hubungan

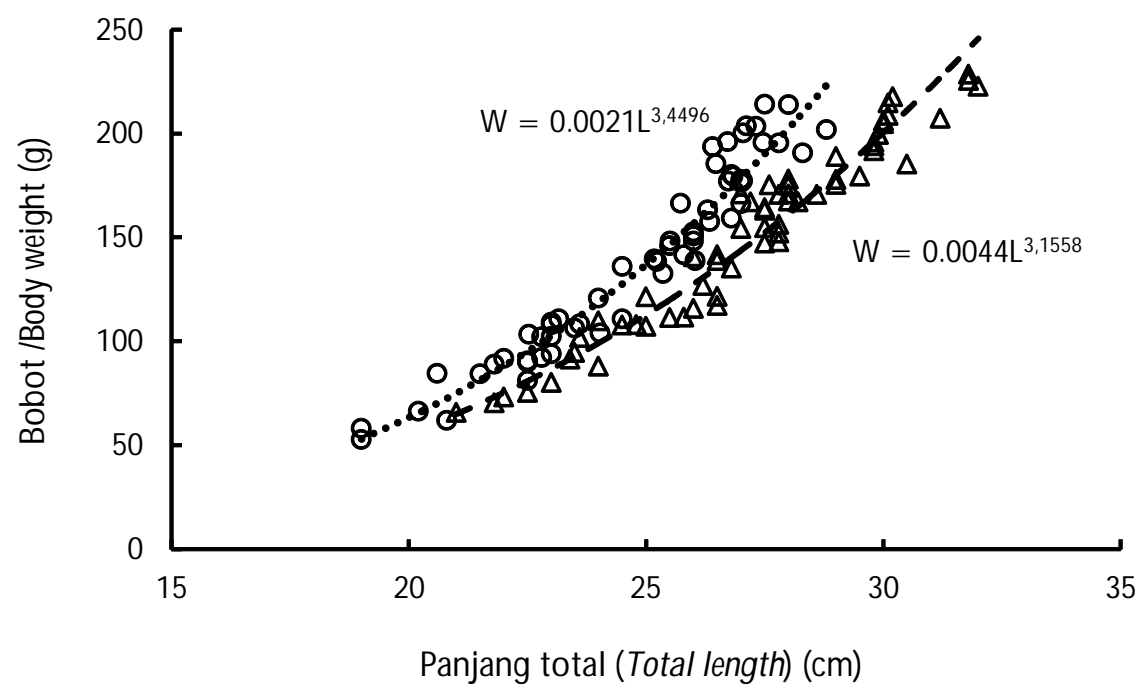

Gambar 1. Hubungan antara panjang total (L) dengan bobot (W) ikan lele Mutiara (Clarias gariepinus) albino (o) dan warna normal $(\Delta$ ) pada akhir tahap pembesaran.

Figure 1. Total length (L) and weight (W) relationship of albino $(o)$ and normal $(\Delta)$ Mutiara African catfish (Clarias gariepinus) at the end of grow-out phase. 
panjang-bobot yang bersifat alometrik positif (AyoOlalusi, 2014), sedangkan yang dipelihara dalam kolam terpal (Omodu et al., 2017) maupun kolam tanah dan kolam beton (Olopade et al., 2015) memiliki hubungan panjang-bobot yang bersifat alometrik negatif.

Selanjutnya, hasil analisis faktor kondisi terhadap data ukuran panjang total dan bobot pada akhir tahap pembesaran menunjukkan bahwa ikan lele Mutiara albino memiliki nilai faktor kondisi rata-rata sebesar $0,88 \pm 0,08$; lebih tinggi $(P<0,05)$ dibandingkan ikan lele Mutiara warna normal yang sebesar 0,73 $\pm 0,05$. Secara umum, hasil analisis faktor kondisi tersebut juga menunjukkan bahwa ikan lele Mutiara albino maupun ikan lele Mutiara warna normal yang berukuran (panjang total dan bobot) besar cenderung memiliki nilai faktor kondisi yang lebih besar dibandingkan dengan ikan lele Mutiara yang berukuran kecil (Gambar 2 dan 3).

Lebih besarnya nilai faktor kondisi ikan lele Mutiara albino dibandingkan yang berwarna normal tersebut mengindikasikan bahwa pada suatu ukuran panjang yang sama bentuk tubuh ikan lele Mutiara albino lebih gemuk (lebih lebar dan atau lebih tinggi). Nilai faktor kondisi ikan-ikan lele Afrika albino yang lain juga lebih besar dibandingkan yang berwarna normal, misalnya pada ikan lele Afrika koleksi BRPI Sukamandi yang berasal dari Mesir (Iswanto et al., 2013b) maupun dari Thailand (Iswanto et al., 2020b) dan juga ikan lele Afrika di Nigeria (Umanah \& Harry, 2017).

\section{Karakteristik Biometrik-Morfologis}

Hasil pengukuran karakter-karakter morfometrik ikan lele Mutiara warna normal dan albino yang dilakukan dalam penelitian ini ditunjukkan pada Tabel 3. Hasil analisis komponen utama terhadap data karakteristik morfometrik tersebut menunjukkan bahwa ikan lele Mutiara warna normal dan albino memiliki karakteristik morfometrik yang berbeda (Gambar 4). Berdasarkan hasil analisis komponen utama tersebut, ikan lele Mutiara albino dapat dibedakan dari yang berwarna normal terutama berdasarkan karakter morfometrik yang berupa panjang kepala, panjang prepektoral (jarak dari ujung moncong ke pangkal sirip dada), lebar kepala, panjang predorsal (jarak dari ujung moncong ke pangkal sirip punggung), tinggi badan maksimum, dan jarak antar mata.

Serupa dengan hasil analisis faktor kondisi, hasil karakterisasi morfometrik pada penelitian ini juga menunjukkan bahwa pada ukuran panjang yang sama, ikan lele Mutiara albino memiliki badan yang lebih gemuk (lebih tinggi) dibandingkan yang berwarna normal, dengan kepala yang lebih lebar dan lebih panjang. Hasil-hasil penelitian karakterisasi morfometrik yang telah dilakukan pada ikan lele Afrika albino yang lain menunjukkan hasil serupa. Ikan lele Afrika albino yang berasal dari Mesir (Iswanto et al., 2016) dan Thailand (Iswanto et al., 2020b) juga memiliki proporsi kepala yang lebih besar dan badan

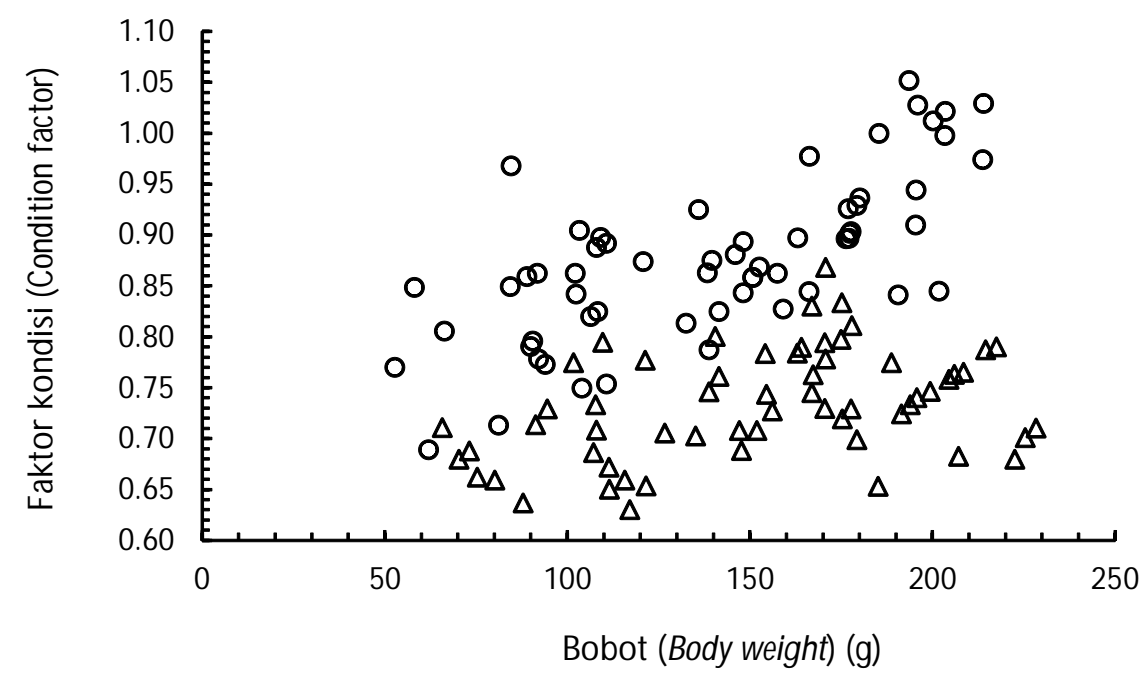

Gambar 2. Nilai faktor kondisi ikan lele Mutiara (Clarias gariepinus) al bino (o) dan warna normal $(\Delta$ ) berdasarkan bobot pada akhir tahap pembesaran.

Figure 2. Condition factor of albino $(o)$ and normal $(\Delta)$ Mutiara African catfish (Clarias gariepinus) based on the body weight at the end of grow-out phase. 


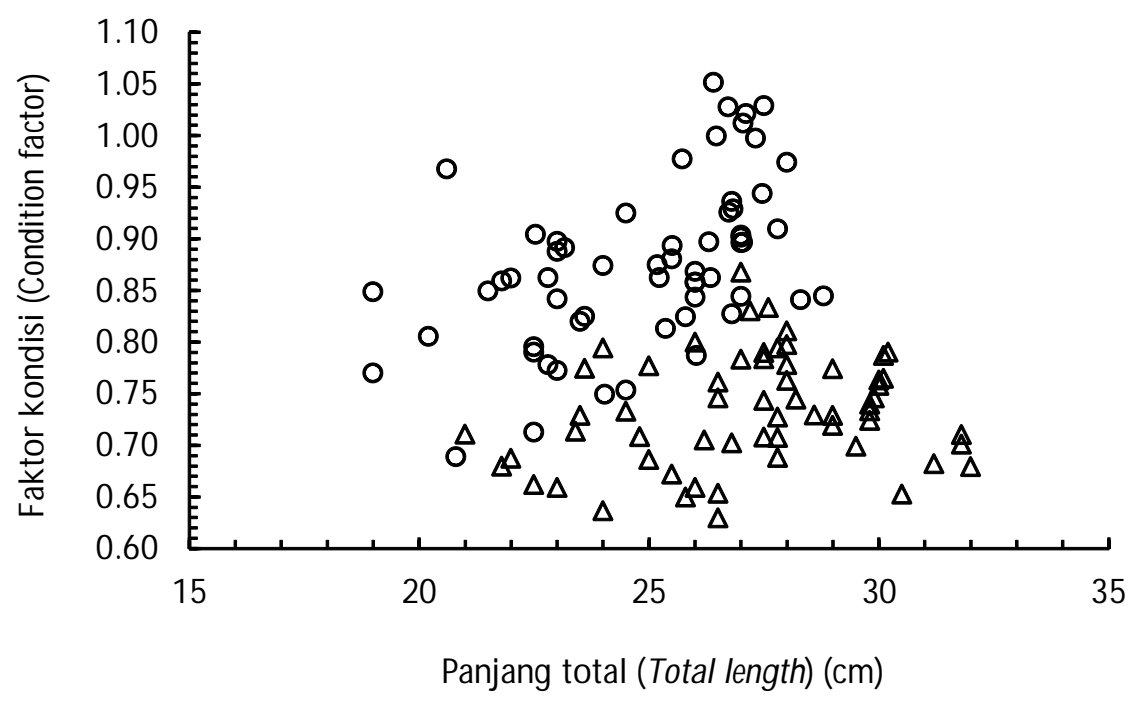

Gambar 3. Nilai faktor kondisi ikan lele Mutiara (Clarias gariepinus) albino (o) dan warna normal $(\Delta)$ berdasarkan panjang total pada akhir tahap pembesaran.

Figure 3. Condition factor of albino $(o)$ and normal $(\Delta)$ Mutiara African catfish (Clarias gariepinus) based on the total length at the end of grow-out phase.

Tabel 3. Karakteristik morfometrik ikan lele Mutiara (Clarias gariepinus) albino dan warna normal dalam persentase panjang standar (\%S) dan panjang kepala (\%R)

Table 3. M orphometric characters of albino and normal Mutiara African catfish (Clarias gariepinus) based on the percentages of standard length (\%L) and head length (\%L)

\begin{tabular}{|c|c|c|}
\hline \multirow{2}{*}{$\begin{array}{l}\text { Karakter } \\
\text { Characters }\end{array}$} & \multicolumn{2}{|c|}{$\begin{array}{l}\text { Ikan lele Mutiara } \\
\text { Mutiara African catfish }\end{array}$} \\
\hline & Albino (Albino) & Normal (Normal) \\
\hline Panjang kepala (\%SS) / Head length (\%L) & $31.66 \pm 1.28$ & $28.43 \pm 0.75$ \\
\hline Lebar kepala (\%S) / Head width (\%L) & $20.97 \pm 1.26$ & $18.03 \pm 0.57$ \\
\hline Panjang moncong (\%K) / Snout length (\%HL) & $22.97 \pm 1.37$ & $22.05 \pm 1.18$ \\
\hline Jarak antarmata (\% $\%$ K) / Interorbital width (\% $\%$ L) & $43.09 \pm 1.52$ & $41.44 \pm 1.87$ \\
\hline Lebar tonjolan oksipital (\%RK) / Occipital process width (\% & $22.08 \pm 0.78$ & $22.13 \pm 1.49$ \\
\hline Panjang tonjolan oksipital (\%RK) / Occipital process length (\%HL) & $13.01 \pm 1.26$ & $15.72 \pm 1.32$ \\
\hline $\begin{array}{l}\text { Jarak tonjolan oksipital ke sirip punggung (\%PS) } \\
\text { Occipital process to dorsal fin distance }(\% \mathrm{SL})\end{array}$ & $3.31 \pm 0.66$ & $4.22 \pm 0.70$ \\
\hline Panjang sirip punggung (\%S) / Dorsal fin length (\%L) & $63.89 \pm 2.03$ & $64.99 \pm 1.50$ \\
\hline Panjang predorsal (\%S) / Predorsal length (\%SL) & $34.97 \pm 1.32$ & $32.65 \pm 0.94$ \\
\hline Panjang prepektoral (\%S) / Prepectoral length (\% \%L) & $23.77 \pm 1.36$ & $20.57 \pm 0.95$ \\
\hline Panjang prepelvis (\%S) / Prepelvic length (\%L) & $45.45 \pm 1.42$ & $44.52 \pm 1.11$ \\
\hline Panjang sirip dubur (\%S) / Anal fin length (\%L) & $42.41 \pm 1.96$ & $42.78 \pm 0.91$ \\
\hline Panjang preanal (\%SS) / Preanal length (\%SL) & $55.02 \pm 1.97$ & $54.47 \pm 1.05$ \\
\hline Tinggi badan maksimum (\%S) / Maximum body depth (\%L) & $18.03 \pm 1.43$ & $15.64 \pm 0.68$ \\
\hline Tinggi batang ekor (\%PS) / Caudal peduncle depth (\%LL) & $8.99 \pm 0.63$ & $7.61 \pm 0.34$ \\
\hline
\end{tabular}




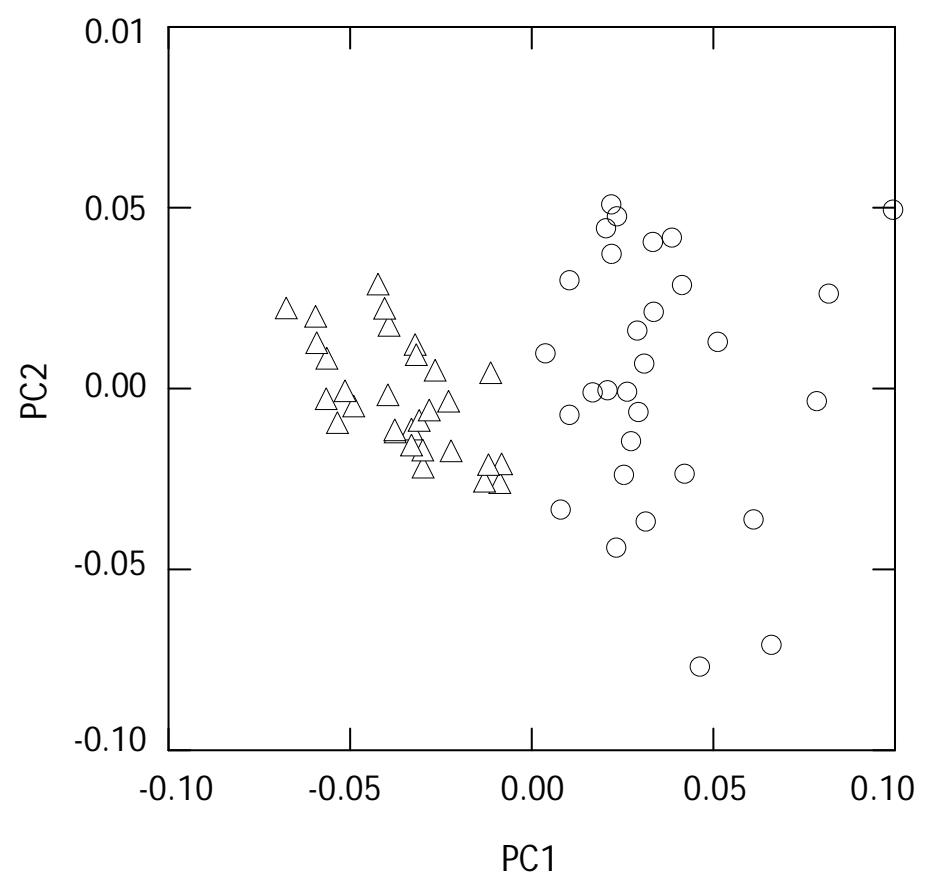

Gambar 4. Diagram pencar skor hasil analisis komponen utama terhadap karakter-karakter morfometrik (dari masing-masing 30 ekor sampel) ikan lele Mutiara (Clarias gariepinus) albino (o) dan warna normal $(\Delta)$ pada sumbu komponen utama pertama $(\mathrm{PC} 1)$ dan kedua (PC2).

Figure 4. Scatterplot of scores resulted from a principal component analysis performed on morphometric characters (of each 30 samples) of albino $(o)$ and normal $(\Delta)$ Mutiara African catfish (Clarias gariepinus) along the first (PC1) and second principal component (PC2) axis.

yang lebih gemuk dibandingkan yang berwarna normal. Tampaknya albinisme pada spesies ikan lele Afrika berkaitan dengan karakteristik morfometriknya, yakni menyebabkan ikan lele Afrika albino memiliki proporsi kepala yang lebih besar (lebih panjang dan lebar) dan badan yang lebih gemuk dibandingkan yang berwarna normal.

Hasil karakterisasi meristik yang dilakukan pada penelitian ini menunjukkan bahwa ikan lele Mutiara warna normal dan albino memiliki jumlah jari-jari sirip dada (berkisar 8-11 buah) dan sirip perut (berkisar 56 buah) yang sama, sedangkan jumlah jari-jari sirip punggung dan sirip duburnya berbeda $(P<0,05)$. Jumlah jari-jari sirip punggung (berkisar 54-68 buah) dan sirip dubur (berkisar 46-56 buah) ikan lele Mutiara albino lebih sedikit dibandingkan jumlah jari-jari sirip punggung (berkisar 64-77 buah) dan sirip dubur (berkisar 50-58 buah) ikan lele Mutiara warna normal.

Serupa dengan ikan lele Mutiara albino, ikan lele Afrika albino yang berasal dari Mesir (Iswanto et al., 2016) dan Thailand (Iswanto et al., 2020b) juga memiliki jumlah jari-jari sirip punggung dan sirip dubur yang lebih sedikit dibandingkan yang berwarna normal. Hasil-hasil penelitian tersebut mengindikasikan bahwa albinisme pada spesies ikan lele Afrika tampaknya juga berkaitan dengan karakteristik meristiknya, yakni menyebabkan ikan lele Afrika albino memiliki jumlah jari-jari sirip punggung dan sirip dubur yang lebih sedikit dibandingkan yang berwarna normal.

\section{KESIMPULAN}

Ikan lele Mutiara albino memiliki karakteristik biometrik-morfologis yang berbeda dari ikan lele Mutiara warna normal, karena memiliki proporsi kepala yang lebih besar dan badan yang lebih gemuk, serta jumlah jari-jari sirip punggung dan sirip dubur yang lebih sedikit. Namun demikian, keragaan aspek zooteknis (pertumbuhan dan sintasan) ikan lele Mutiara albino relatif sama dengan yang berwarna normal, sehingga potensial sebagai komoditas budidaya. 


\section{UCAPAN TERIMA KASIH}

Terima kasih disampaikan kepada para mahasiswa praktek kerja lapangan di hatchery ikan lele BRPI Sukamandi atas bantuan teknisnya selama tahap pemeliharaan larva, pendederan, dan pembesaran.

\section{DAFTAR ACUAN}

Agnese, J.F., Teugels, G.G., Gal busera, P., Guyomard, R., \& Volckaert, F. (1997). Morphometric and genetic characterization of sympatric populations of Clarias gariepinus and $C$. anguillaris from Senegal. Journal of Fish Biology, 50, 1143-1157.

Ajani, F. \& Adeyemo, O.K. (2012). Nitrite intoxication of Clarias gariepinus at different water temperatures. International Journal of Fisheries and Aquaculture, 4(4), 77-80.

Ayo-Olalusi, C.I. (2014). Length-weight relationship, condition factor and sex ratio of African mud catfish (Clarias gariepinus) reared in flow-through system tanks. Journal of Fisheries and Aquatic Science, 9(5), 430-434.

Degani, G., Ben-Zvi, Y., \& Levanon, D. (1988). The effect of different dietary protein sources and temperatures on growth and feed utilization of African catfish Clarias gariepinus (Burchell). The Israeli Journal of Aquaculture - Bamidgeh, 40(4), 113-117.

Froese, R. (2006). Cube law, condition factor and weight-length relationship: History, meta-analysis and recommendations. Journal of Applied Ichthyology, 22, 241-253.

Hoffman, L.C., Prinsloo, J.F., Theron, J., \& Casey, N.H. (1995a). The genotypic influence of four strains of Clarias gariepinus on the larvae body proximate, total lipid fatty acid, amino acid and mineral compositions. ComparativeBiochemistry and Physiology, 110B(3), 589-597.

Hoffman, L.C., Prinsloo, J.F., Theron, J., \& Casey, N.H. (1995b). A chemical comparison between the golden and normal coloured strains of the African sharp tooth catfish, Clarias gariepinus (Burchell 1822). Journal of Applied Ichthyology, 11, 71-85.

Iswanto, B., Imron, Suprapto, R., \& Marnis, H. (2013a). Keragaan pertumbuhan ikan lele Mesir (Clarias gariepinus Burchell, 1822) strain merah pada tahap pembenihan dan pendederan. Prosiding Forum Inovasi Teknologi Akuakultur 2013, Mataram, 12-13 Juni 2013. Jakarta: Pusat Penelitian dan Pengembangan Perikanan Budidaya, hIm. 639-647.

Iswanto, B., Suprapto, R., Marnis, H., \& Imron. (2013b). Hubungan panjang total-bobot dan faktor kondisi ikan lele strain Mesir (Clarias gariepinus Burchell, 1822) merah pada ukuran konsumsi.
Prosiding Seminar Nasional Perikanan Indonesia 2013. Jakarta, 21-22 November 2013, hlm. 76-81.

Iswanto, B., Imron, Suprapto, R., \& Marnis, H. (2015). Embryonic and larval development of a red strain of the Egyptian African catfish (Clarias gariepinus Burchell, 1822). Indonesian Aquaculture Journal, 10(1), 19-31.

Iswanto, B., Suprapto, R., Marnis, H., \& Imron (2016). Morphological characteristics of a red strain of the Egyptian African catfish (Clarias gariepinus Burchell 1822). Indonesian Aquaculture Journal, 11(2), 49-59.

Iswanto, B., Imron, Suprapto, R., Suwargono, P., Pangestika, M.F., \& Ilmalizanri. (2020a). Tingkat albinisme ikan lele Mutiara (Clarias gariepinus). Buletin Penelitian Pemuliaan Ikan, 9(1), 11-12.

Iswanto, B., Suprapto, R., \& Suwargono, P.(2020b). Hubungan panjang-bobot, faktor kondisi dan karakteristik biometrik ikan lele Afrika (Clarias gariepinus) albino asal Thailand. Berita Biologi, 19(3A), 249-256.

Ndubuisi, U.C., Chimezie, A.J., Chinedu, U.C., Chikwem, I.C., \& Alexander, U. (2015). Effect of $\mathrm{pH}$ on the growth performance and survival rate of Clarias gariepinus fry. International Journal of Research in Biosciences, 4(3), 14-20.

Olopade, O.A., Gbaramana, M., \& Zabbey, N. (2015). Estimation of length-weight relationship and proximate composition of catfish (Clarias gariepinus Burchell, 1822) from fwo different culture facilities. Turkish Journal of Agriculture - Food Science and Technology, 3(7), 566-570.

Omodu, A.O., Solomon, R.J., \& Wilfred-Ekprikpo, P.C. (2017). Length weight relationship of Clarias gariepinus (catfish) fed with local feeds. New York Science Journal, 10(5), 46-59.

Onyia, U.L., Ochokwu, I.J., \& Akume, C.P.(2016). Growth and survival of normal coloured and albino Clarias gariepinus and their reciprocals hybrids. Nigerian Journal of Fisheries and Aquaculture, 4(1), 22-27.

Onyia, U.L., Philip, B., \& Jegede, O.I. (2018). Evaluation of reproductive indices and growth of normal, albino Clarias gariepinus and their reciprocals in hatchery conditions. Journal of Natural Sciences Research, 8(16), 7-14.

Prinsloo, J.F. \& Schoonbee, H.J. (1989). Notes on comparison of the catchability and growth of a red and normal variety of the sharp tooth catfish Clarias gariepinus (Burchell) stocked together in fish production ponds. Water SA, 15(3), 191-194. 
Prinsloo, J.F., Schoonbee, H.J., \& Theron, J. (1989a). The use of a red strain of the sharp tooth catfish Clarias gariepinus (Burchell) in the evaluation of cannibalism amongst juveniles of this species. Water SA, 15(3), 179-184.

Prinsloo, J.F., Schoonbee, H.J., \& van der Walt, I.H. (1989b). Production studies with red and normal varieties of the sharptooth catfish Clarias gariepinus (Burchell) using a mixture of minced fish, bakery-floor sweepings and a formulated pelleted diet. Water SA, 15(3), 185-190.

Prinsloo, J.F., Schoonbee, H.J., \& Hoffman, L.C. (1990). A comparison of the fecundity of two strains of the sharptooth catfish Clarias gariepinus. South African Journal of Wildlife Resources, 20(3), 100-103.
Schram, E., Roques, J.A.C., Abbink, W., Spanings, T., de Vries, P., Bierman, S., van de Vis, H., \& Flik, G. (2010). The impact of elevated water ammonia concentration on physiology, growth and feed intake of African catfish (Clarias gariepinus). Aquaculture, 306, 108-115.

Teugels, G.G. (1986). A systematic revision of the African species of the genus Clarias (Pisces: Clariidae). Annales Musee Royal de l'Afrique Centrale, 247, 1-199.

Umanah, S.I. \& Harry, E.H. (2017). Comparative growth performance of two strains of African sharptooth catfish, Clarias gariepinus (normally pigmented and albino) fed commercial catfish diets in collapsible tarpaulin tanks. CARD International Journal of Agricultural Research and Food Production, 2(2), 144-160. 